'Federal University of Rio de Janeiro, Brazil

yvonnemaggie@gmail.com

Yvonne Maggie'

\title{
NO UNDERSKIRTS IN AFRICA: EDISON CARNEIRO AND THE "LINEAGES" OF AFRO-BRAZILIAN RELIGIOUS ANTHROPOLOGY ${ }^{1}$
}

Translated into English by David Rodgers

I was very young when I saw Edison Carneiro for the first time. It was my second year of high school, in 1962, and I had no idea about the existence of anthropologists, still less of anthropology. I came from a family of physicists and chemists. There was one teacher at my college who encouraged the students to research topics related to Brazilian folklore. Fascinated by her classes, I began to take part in activities organized by the school like the popular dances and revelries (folguedos). I found it easy to memorize songs. I asked the teacher if she could suggest a library where I could find books and other material on folklore. Somewhat uncertain and very shy, I began to attend the recently inaugurated library of the Campanha de Defesa do Folclore Brasileiro (CDFB) [Action for Brazilian Folklore Protection], on Pedro Lessa Street, in Rio de Janeiro. A new world opened up for me on pleasant afternoons when I could watch popular artists wander about and chat to the staff. I began to read my first books on what were conventionally called Afro-Brazilian cults. And so began my initiation into the social sciences. Until then I had spent my time in experimental physics labs filled with exotic pieces of equipment, accompanying my father on equally unforgettable afternoons in the former National Faculty of Philosophy.

It was also at the CDFB that I met one of its most important founders, Edison Carneiro, a member of the group of so-called folklorists - or the folkloric movement, as they liked to label themselves. The folkloric movement, 
active on the Brazilian scene from 1947 to I964, was described and analysed in the beautiful book by Luiz Rodolfo Vilhena (I997). There the author shows us why the movement was so important and also why folklore ceased to be a prestigious topic in the social sciences. He describes the creation of institutions like the National Commission of Folklore, in I947, whose first president was Renato Almeida. The book also relates the events leading up to the creation in 1958 of the CDFB. Edison Carneiro was a member of the CDFB's technical committee until I96I, and its executive director from then until I964, when he was deposed by the military coup. The coup put an end to a vigorous movement whose mission, as Vilhena points out, had gone beyond preserving Brazilian folklore to building the Nation.

At that time I had little notion of what happened in the complex structuring of an institution as important as the CDFB. I merely perused the journals published there, which I still fondly keep today.

I first encountered Edison Carneiro in the inaugural class of a course on folklore. It was a stimulating lesson and I, still a college student, ventured to ask a question about the origins of the cults he was analysing. I must have committed a faux pas: my question referred to the African origins of the cults and the reply from Edison Carneiro - who I began to understand better after reading his work and, above all, after learning more about him through the wonderful book by Ruth Landes (2002), The City of Women - was not particularly friendly. Unfortunately I forgot what he said, but while his emphatic, not to say authoritarian, tone made me recoil from my idea of studying Brazilian folklore, but it did inspire me to look for an answer to my query. Undoubtedly I had stepped on quicksand because this theme was precisely the one he was discussing, showing the importance of the cults of Bantu origin in Rio de Janeiro. I return to the issue of the origin of the cults later in this text.

My purpose in telling this story is not to paint Edison Carneiro as authoritarian. I accompanied him over the ensuing years and was able to experience his patience and kindness at other moments. But that day I felt extremely ignorant and regretted asking a question that had perhaps offended my teacher.

During this period from 1962 to 1964 , which I spent on afternoons reading in the Library of the $\mathrm{CDFB}$, many things changed in my way of thinking. But the lesson given by Edison Carneiro, a key figure in my life, remained vivid enough in my mind to persuade me to study not folklore but the socalled Afro-Brazilian religions, a theme on which I have focused throughout my career since my master's dissertation in I975 (see Maggie, 200I). This is the perspective from which I intend to discuss Edison Carneiro's contribution to the study of so-called Afro-Brazilian culture. ${ }^{2}$ 


\section{WHO WAS EDISON CARNEIRO?}

Born in Salvador, on August I2th I9I2, he died in Rio de Janeiro, where he had lived since 1939, on December 2nd 1972. Obtaining a law degree from the Bahia Faculty of Law in 1936, he was one of the most active members of the folkloric movement from I947 onward, organizing various congresses and helping set up state folklore commissions. He was the first president of the National Commission of Folklore and director of the CDFB from I96I to I964. During this period, as well as founding the journal Revista do Folclore, he inaugurated the Amadeu Amaral Library and began work on the creation of the Museum of Folklore, which was finally opened in 1978 when the CDFB transformed into the National Institute of Folklore, today the Centro Nacional de Folclore e Cultura Popular (CNFCP) [National Centre of Folklore and Popular Culture].

Edison Carneiro wrote on many topics, participated actively in the folkloric movement, studied the various styles of candomble of Bahia, which he knew more about than anyone, and was one of the organizers, perhaps the most important, of the Second Afro-Brazilian Congress, held in Salvador in 1937. The first Congress had been organized by Gilberto Freyre in 1934, in Recife. Carneiro was an active militant of the Brazilian Communist Party. During the New State regime, pursued by the police, he found refuge at the terreiro [temple] Ilê Axé do Opô Afonjá, due to the friendship shown to him by Aninha (Eugênia Ana dos Santos), perhaps the most renowned mãe-desanto [priestess] of Bahia. ${ }^{3}$ Aninha instructed her daughter, who later became famous as Senhora, ${ }^{4}$ to look after him. This fact was never revealed by Aninha, still less by Senhora, and only became public when Edison Carneiro himself announced in his book Ladinos e crioulos (1964) that he had spent several days in hiding at the Peji de Oxum [sacred room for the divinity Oxum] in the Ilê Axé do Opô Afonjá. ${ }^{5}$ Deoscóredes M. dos Santos, the son of mãe-desanto Senhora, Aninha's successor, also revealed the fact in his own book, published in 1962, on the famous casa [temple]. This passage of Edison Carneiro's life shows the intimacy and friendship that he enjoyed among the most important terreiros of Salvador, and provides us with a valuable insight into his relation with this field of study. ${ }^{6}$

As Ana Carolina Nascimento (2009: 16) writes: "Throughout his career, [the] author moved between very different worlds: the social sciences and folklore; Brazilian and American anthropology; the universe of intellectuals and the native universe; Rio de Janeiro and Bahia."

Edison Carneiro, at the same time as enjoying a close relationship with the terreiros, was also immersed in the universe of the social sciences. This famous photo shows, from left to right, Lévi-Strauss, Ruth Landes, Charles Wagley - the American researcher who launched the Columbia University/ 
Bahia State Agreement,7 Heloísa Alberto Torres - daughter of the eminent essayist and politician Alberto Torres and whose authorization was essential for carrying out fieldwork at the time, a young Luis de Castro Faria - later emeritus professor of the National Museum, who, as a member of the $\mathrm{Mu}$ seum team, accompanied Lévi-Strauss on his field trip to Central Brazil, Raimundo Lopes, a researcher from the Museum, and Edison Carneiro who, in I939, was better known perhaps as a journalist, although he had already published the book Negros Bantos (1937). ${ }^{8}$

\section{EDISON CARNEIRO AND THE "LINEAGES" OF AFRO-BRAZILIAN RELIGIOUS ANTHROPOLOGY}

Many approaches exist when it comes to speaking about Edison Carneiro, given that he was active in various worlds. I have chosen to describe the Edison Carneiro I knew better, the version who vividly experienced and described candomble in Bahia and was one of the scholars to investigate the nationalization of African culture in Brazil. He studied and revealed what became known as candomblé de caboclo, a term coined by Sabina, a mãe-desanto who, though initiated in a Nagô temple, later turned to the worship of ancestral spirits. ${ }^{9}$

Edison Carneiro approached the theme of Afro-Brazilian religions, of Africa in Brazil, from a perspective centred more on comprehending the paths and transformations that this Africa underwent from the original continent of the slaves to Brazil. His debut book - Religiões Negras (I936) - is strongly influenced by communist ideology. It initiates a trajectory that to some extent distinguishes him from many of his contemporaries. During the same decade, Arthur Ramos was the leading exponent of studies on African-based religions in Brazil and was involved in searching for the origins and producing a history of what was defined by him as the "transplantation of African culture" to Brazil. Arthur Ramos was a follower of Melville Herskovitz, an anthropologist who invested in the search for African origins in the Americas. Ramos became the most important scholar of African religions in Brazil and, like Herskovitz, sought an "authentic Africa," defined as Nagô Africa, that had been "transplanted" to Brazil.

Edison Carneiro accompanied Arthur Ramos in many ventures, as shown by the correspondence between the two, meticulously analysed by Vivaldo Costa Lima and Waldir Oliveira (1977). In 1937, Edison Carneiro organized the Second Afro-Brazilian Congress, held in Salvador, with Aidano do Couto Ferraz. The papers from the congress were gathered in the book 0 Negro no Brasil, published in 1940 by the Civilização Brasileira publishing house, in the Collection Library for Scientific Divulgation directed by Arthur Ramos - Professor of Anthropology at the now defunct National Faculty of 


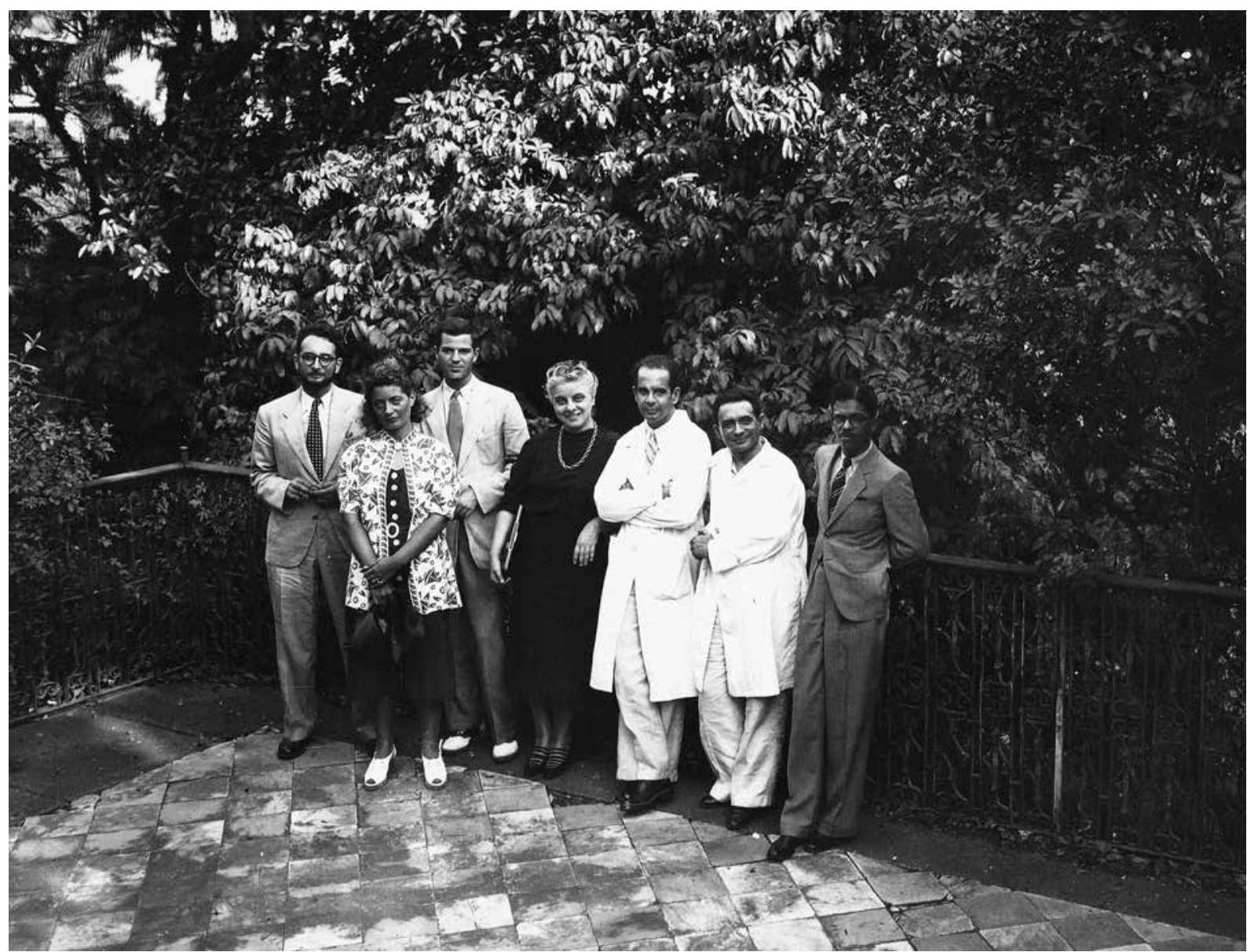

In the Princesses' Garden (Jardim das Princesas) are, from left to right, Claude Lévi-Strauss, Ruth Landes, Charles Walter Wagley, Heloísa Alberto Torres, Luís de Castro Faria, Raimundo Lopes da Cunha and Edison Carneiro. Arquivo do Museu Nacional [National Museum Archive], Rio de Janeiro.

Reference: BR MN JF.o.MN, DR.I08/75. 
Philosophy, founded the year before. ${ }^{\text {II }}$ All of this was the beginning of anthropology and the studies of Afro-Brazilian cults, the beginning of a life.

The Second Afro-Brazilian Congress followed the style of the folkloric movement, since as well as the presentation of scientific works by all those studying the theme of Afro-Brazilian culture, there was music, religion, cuisine and so on, with the mass participation of the most eminent figures from the world of candomblé, such as Aninha and the babalaô Martiniano Eliseu do Bonfim. Martiniano, the son of freed African slaves and perhaps the most important "informant" of Nina Rodrigues, had lived in Lagos, Nigeria. In his talk at the congress, he displayed all his political skill, as would Aninha, by describing the importance and origin of the Minister of Xangô, a post invented by the two of them. The Ministers of Xangô are honorary posts, created so that important personalities from Bahia could also have an important position in the religious and administrative hierarchy of the terreiros and therefore protect the temples from the police raids. Aninha welcomed the congress' participants at a festival described as "spectacular" held in the barracão [the great hall of the temple where they perform the possession rituals] of the Axé do Opô Afonjá. Finally, Edison Carneiro organized with Aninha and Martiniano an association bringing together the Salvador terreiros: União das Seitas Afro-Brasileiras [the Union of Afro-Brazilian Sects]. This entity also performed a very important role in history of the social acceptance and legitimization of the cults since at the same time while uniting the terreiros, it also defined those deemed authentic, distinguishing them from the "inauthentic," "charlatan" and "impure" or the "macumbas for tourists."

Both the first and second congress were important to delimiting AfroBrazilian culture as a field of study seen from the perspective of a more academic anthropology and from the perspective connected to folklore studies. In effect, the two congresses were organised with the aim of uniting academics scholars with the intellectuals linked to the folklorist movement and both groups with important figures from these religious worlds.

It was during this period in the I930s that the expression "Afro-Brazilian culture" entered the vocabulary of the social sciences in Brazil and the United States. In 1937 Edison Carneiro published Negros Bantos, which initiated a search for other origins, previously considered less authentic by the anthropological mainstream, that broke with the traditional rules of Nagô candomblé, considered purer and of Sudanese origin. Edison Carneiro was venturing into a field that Roger Bastide ${ }^{\mathrm{I2}}$ defined pejoratively as "macumba for tourists" (see Bastide, I973). However, in Nina Rodrigues' previous view (2006), there was much more belief and fear of sorcery involved in the Bantu cults than Bastide could ever imagine when he described the "macumbas" of Rio de Janeiro as religious forms "distorted" by the material interests of the white population. ${ }^{\mathrm{I} 3}$ Bastide wrote two books, in I96I and I97I, important works in defining the field of studies of Afro-Brazilian religions. 
In order to fully comprehend Edison Carneiro's position in this world of studies concerning so-called Afro-Brazilian religions, we need to recognize the importance of intellectuals in constructing this field of research and the terreiros considered the more legitimate and authentic heirs of the Nagô tradition.

The most important work in terms of understanding this issue is Vovó nagô e papai branco: usos e abusos da África no Brasil (1988), by Beatriz Góis Dantas, a book that unravels the involvement of anthropologists and Bahian intellectuals in the construction of this religious field. Beatriz Góis Dantas makes a path-breaking discovery: after an exhaustive reading of Arthur Ramos and the scholars researching "traditional" Bahian candomblé, Dantas was studying a terreiro in the town of Laranjeiras, in Sergipe, when she discovered an authentic Nagô terreiro with characteristics very different from those defining the authentic Nagô of Bahia. This began her critical inquiry into the construction of what had been consecrated as authentic in the literature on Afro-Brazilian cults. The book is already a classic and has recently been translated into English. ${ }^{14}$ Indeed, since its first publication in I988, this is the work most cited both in Brazil and abroad. ${ }^{15}$ It is now a benchmark work. However, although Dantas lists Edison Carneiro among the scholars who searched for an authentic Africa, as Nascimento wrote (2009), we need to rethink his position in this field.

Edison Carneiro was located alongside Arthur Ramos in the intellectual field, yet nonetheless he set out in search of a new authenticity, that of the Bantu cults. One year after publishing Negros Bantos in 1938, he met and chaperoned a young Jewish American anthropologist, Ruth Landes, who had come to Brazil to study its black population. This would prove to be a landmark in Edison Carneiro's life and it is this relation with Landes that I shall use as a basis to outline the "lineages" that composed and still shape the field of studies of Afro-Brazilian culture.

Using kinship as a metaphor to refer to these different approaches is, in a way, a tour de force. Lineages are exclusive by definition, academic affiliations less so. Melville Herskovitz and Ruth Benedict were students of Franz Boas and, in this sense, were similar insofar as they both looked to comprehend the symbolic aspects of the cultures they studied. Melville Herskovitz, like Roger Bastide and Arthur Ramos, sought to understand AfroBrazilian religions through a diachronic and almost diffusionist approach. Ruth Benedict, Donald Pierson, Robert Park, Franklin Frazier and Ruth Landes were interested and involved with the more synchronic aspects of social life. Edison Carneiro and Ruth Landes worked to understand life in the terreiros through this line of study. However, Edison's intellectual affiliation was more ambiguous. The relation between him and Ruth Landes provides a clue to understanding this ambiguity, as we shall see below (see the study by Andreson, 20I2). 


\section{EDISON CARNEIRO, RUTH LANDES AND THE CITY OF WOMEN}

In the prologue to her book The City of Women, Ruth Landes wrote: "This book about Brazil does not discuss race problems because there were none. It simply describes the life of Brazilians of the Negro race, a gracious poised people whose charm is proverbial in their own land, and undying in my memory" (Landes, 2002: 34).

This phrase was written in 1939 when Ruth Landes was living in Salvador and working and living in close proximity with some of the leading exponents of Afro-Brazilian cults. Her training in anthropology at New York's Columbia University, under the supervision of Ruth Benedict, enabled her to describe the everyday world of the terreiros in such a personal and intimate form that her book became the first to approach the participants in candomblé as real-life people. The City of Women, along with $\mathrm{O}$ animismo fetichista dos negros baianos (2006) ${ }^{16}$ by Nina Rodrigues, were the first to shift beyond a description of the origins of ritual elements to describe the flesh, blood and spirit of those practicing them.

Her book was only published in the United States in 1947, but before then Ruth Landes had written an article entitled "Matriarcado cultural e homossexualidade masculina" [A Cult matriarchate and male homosexuality], which openly discussed the homosexuality of the pais-de-santo and mães-desanto, the Bahian cult leaders. This was a topic then - and for a long time after - considered taboo, though much later described by Vivaldo Costa Lima in his book Família de santo (1970). Peter Fry (1988) revived the debate with a critical reading of Ruth Landes' findings. The topic then began to be studied with more attention through the works of Maria Lina Leão Teixeira (1988) and Patrícia Birman (I995).

The article and a research report by Ruth Landes were read by Melville Herskovitz and also by Arthur Ramos, who subjected it to a severe critique in his text "Pesquisas estrangeiras sobre o negro brasileiro" [Foreign research on the Brazilian Negro] in Aculturação do negro no Brasil (1942). This fight, a full-blooded war in fact, reveals the structure and different intellectual affiliations of this field of studies.

Edison's response to Ramos' violent and accusatory article on Ruth Landes only became public twenty years later in the essay "Uma falseta de Arthur Ramos" [The unfairness of Arthur Ramos], published in Ladinos e crioulos (I964). In the text, Edison defends his friend and great source of inspiration, claiming that the violence of Arthur Ramos' critique could be traced to the fact that Ruth Landes had not ingratiated herself enough with the most important anthropologist and scholar in the area. But despite this delay in defending her, Edison Carneiro did not abandon Ruth and was never abandoned by her. In the publication of the 1967 Brazilian edition of the book 
The City of Women, as in the American edition of I947, he revised the book and helped her with explanatory notes and corrections of terms and people's names.

\section{AN UNFAIR ACT BY ARTHUR RAMOS?}

Arthur Ramos' unfairness, as the folklorist perceived his action, and the relation between Edison and Ruth Landes are not mentioned here in order to reopen old personal sores in a kind of anachronistic voyeurism: rather, I wish to understand what the disputes meant in terms of academic affiliations and ways of seeing the world.

The ways in which foreign intellectuals viewed Brazil at the beginning of the I930s were undoubtedly very different to today, but it is still possible to assert with confidence that a structure - a set of intellectual affiliations - persists, connecting past and present. Many of these scholars, especially Americans, were in Brazil and Bahia and became enchanted by the singularity of race relations in the country. Ruth Landes was one of them. And who was she connected to? Ruth Benedict, her supervisor, and her friend Robert Park, supervisor of Donald Pierson, and Franklin Frazier, the first black American sociologist, also close to Franz Boas. Franklin Frazier was a professor of Fisk University, a university for black students in Tennessee, and came to Brazil during this period, shortly before Ruth Landes, to research black families. It is in these connections that, in my view, the true genealogy of the conflict that generated "the unfair act of Arthur Ramos" is located and can be understood.

The fact that Ruth Landes had spoken openly about homosexuality in candomblé obviously shocked and, therefore, "stained" the image of the men participating in this religious world at that time. The lack of ingratiation to which Edison Carneiro referred in his reply to Arthur Ramos some twenty years after the event also undoubtedly played a part in the story. However, the conflict is conceptual in nature and entwined with the dispute over distinct ways of interpreting Brazil and the Americas in general. On one side, the worshippers of Africa, whose most prominent exponents were Melville Herskovitz in the United States and Roger Bastide and Arthur Ramos in Brazil. On the other side, the approaches founded by Ruth Benedict, involving the sociologist Franklin Frazier and, above all, Robert Park. In the I93os the latter was already over 70 years old and was a professor at Fisk, though he had originally participated in the group that founded sociology at Chicago.

As Licia do Prado Valladares (2010) shows, Park was enormously important in attracting American anthropologists to come to Brazil in the I930s. Robert Park was in Brazil in 1934 where he met Arthur Ramos and Oliveira Vianna, and acquired Nina Rodrigues' book Os Africanos no Brasil (1932). Park suggested to Donald Pierson that he should come to study the country's racial situation 
and even went as far as to rethink the meaning of the melting-pot when he came to write the Introduction to Pierson's book (I97I: 82):

In suggesting the possibility of future studies in the wake of this one, I am taking into account the following: I) Brazil is one of the most important melting-pots of races and cultures in the world, where miscegenation and acculturation are being processed; and 2) that the comparative study of problems of race and culture will probably assume special importance during this period when the structure of the world order seems to be disintegrating due to the dissolution of the physical and social distances on which this order seems to rest (apud Valladares, 2010: 42).

Robert Park saw Brazil as a very different society to the United States and other parts of the world, though still a melting-pot - as Americans typically define a society created from the immigration and mixture of many peoples. Valladares also claims that Ruth Landes kept up an intense correspondence with Robert Park while she was in Bahia, since she intended to publish Edison Carneiro's writings and Park could help her in this venture.

Donald Pierson highlighted the differences between Brazil and the United States of America. In the preface to the second edition of his book Brancos e Pretos na Bahia, in I97I, he answered the critiques made in the I950s by Florestan Fernandes and Roger Bastide, and related a fact that, he said, would help explain the origin myth of the struggle against racism in Brazil.

Donald Pierson was probably the first person to provide a detailed account of so-called race relations in Brazil. Although other scholars like Raimundo Nina Rodrigues and Manuel Querino had also spoken about race relations in the early years of these studies, Pierson was probably the first to make an essential contrast between Brazil and the United States. In the preface to the new edition of the book, he refuted the critiques made years earlier by the members of the group that participated in the UNESCO Project, especially Roger Bastide, who wrote that Pierson had claimed racial prejudice was absent in Brazil. Pierson considered these critiques unfair, and in the preface threw cold water on one of the origin myths of the struggle against racism in Brazil. According to Pierson, the case that had led to the promulgation of the Afonso Arinos Law in 1950 may have been misleading. The famous story that an American ballerina had been prevented from entering a big hotel in São Paulo, which mobilized Afonso Arinos and prompted him to redraft the text of the law that carries his name and considers racism a crime, unfolded somewhat differently. According to Pierson, she had more than likely been prevented from entering the hotel for moral reasons, rather than racial, since a week before the event he had dined in the same hotel with friends, a black Brazilian couple, without being disturbed in any way by the managers or the waiters. In fact the couple had even stayed in the hotel. ${ }^{17}$ 


\section{FRANKLIN FRAZIER AND MELVILLE HERSKOVITZ: THE BLACK FAMILY IN BAHIA - AFRICA IN BRAZIL OR THE BRAZILIANIZATION OF AFRICA}

To understand the debate better, we need to turn to another fight, the one between Frazier and Herskovitz concerning black families in Brazil. E. Franklin Frazier, author of Black Bourgeoisie (1957), had been in Brazil in I940 and over a period of six months had interviewed Bahian families living near to the famous terreiro of Gantois. His observations and interviews led him to hypothesize that, in Brazil, Africa had been completely incorporated in Brazilian patterns. In an article Frazier wrote (1942: 469-470):

[...] it is not surprising that these families showed considerable racial mixture. None of the persons interviewed regarded themselves as Negroes but simply as Brazilians. They used the term black as a means of identifying themselves with reference to color but not as to race. As far as possible, we attempted to construct genealogical trees showing the racial origin of each person interviewed. This information was, of course, limited by their knowledge of their ancestors. About a fourth, or eleven, of the persons interviewed had no knowledge of their grandparents.

He added:

Whatever influence African traditions might have exerted upon the family organization of their African forebears in the New World had evidently been lost through racial mixture and the mobility of these families.

Responding to Frazier's article, Melville Herskovitz, who had also researched families in Bahia, defended a contrary position, emphasizing the African traits making up the Bahian family. Frazier wrote a rejoinder in which he backs up his arguments and rejects the presence of Africa in the families he studied. Curiously the two may well have interviewed the same families since the debate was over the meaning of various relations, including, for example, the cultural meaning behind men having amásias [mistresses]. While Frazier interpreted the fact to be characteristic of the habits of poor families in the Americas, Herskovitz argued that it was a survival of African polygamy. ${ }^{18}$

In fact we are dealing with two theoretical affiliations from different anthropological perspectives on culture: one that identifies and explores an Africa in Brazil; the other that investigates Brazilian life and the reconstruction of an Africa in its own terms. This opposition between Herskovitz and Frazier also took place between Herskovitz and Park. While the former - for Sidney Mintz and Richard Price (1992), the inventor of the notion of AfroAmerican culture - was more interested in the traces of African culture that survived the process of acculturation, Park, like Frazier, was more interested in the processes of assimilation. 


\begin{abstract}
His [Herskovitz's] relation with Robert Park is somewhat ambiguous since, despite both men being interested in comparative studies and race relations, they held different positions concerning the role of African culture in the process of acculturation in the "New World." While Herskovitz argued that diverse aspects of the traces of African culture remained in the process of acculturation (like possession), Park was more interested in the process of assimilation and the social mobility of the blackpopulation (Valladares, 2010: 45).
\end{abstract}

The issue that provoked the debate between these authors in the mid twentieth century had, in fact, originated much earlier, at the start of the century, when Raimundo Nina Rodrigues (2006) evoked "the fetishistic animism of the Bahian Negroes," an expression that became the title of his book on candomblé in Bahia - $\mathrm{O}$ animismo fetichista dos negros baianos. The ambiguity between these two positions was already present in this first urban Brazilian ethnography with Nina Rodrigues sometimes referring to the cults as black/African, sometimes as Bahian. In this sense, he had already anticipated the debate that extends into our present, among intellectuals and scholars, and among the practitioners of these religions, as we wrote in the preface to a new edition of Nina Rodrigues' book, celebrating the centenary of his death (Fry \& Maggie, 2006).

\title{
NO UNDERSKIRTS IN AFRICA
}

Imagine yourself in a slave ship, taken from your birthplace by force, alone and isolated, without family, without siblings and without the material objects of your culture. Imagine arriving at the destination port in some coastal city in the Americas. Nobody speaks your language, you have no work colleagues, nor followers of your religion or belief. What would you have brought of your original culture? This is how Sidney Mintz and Richard Price (I992), the two great scholars of slavery in North America, begin the book The Birth of African-American Culture. The image is powerful. We are used to depictions of slave ships printed on designs and iconographic representations of slavery, but the designs, though evoking the hardship and suffering of the crossing, do not give us a precise dimension of what happened in this period during which thousands of slaves from various parts of Africa were shipped to the Americas and Brazil in particular.

However, we can imagine, as Mintz and Price did (1992), that although they did not bring objects and had been left to face the challenges encountered in the New World alone, in their minds they brought the principles that organized their culture. In this way the belief in spirits, sorcery and many other phenomena survived in Brazil, all of them organized through principles underlying the culture of origin of the slaves. These principles, in contact with others that abounding in the life of the big plantations, the mines, the 
slave-owner houses and slave quarters, produced an original African culture and, incredibly, a completely Brazilian culture. ${ }^{\text {I9 }}$ This new culture formed from the encounter or fusion of Africa and Brazil was denominated AfroBrazilian culture in both the specialized literature and everyday language. Since the beginning of colonization in the Americas, the question has been posed: what did slaves bring from their cultures of origin? Melville Herskovitz, conducting research in Suriname with his wife Frances, also an anthropologist, wrote the famous The Myth of the Negro Past (I94I), the work that coined the expression "Afro-American culture." In this book, Melville Herskovitz claims that in the United States, Africa, the Caribbean and Brazil, African culture flourishes almost as intact as in many parts of Africa. It was his research in Suriname with the Maroons - runaway black slaves, the Saramaka, who even today possess a deep knowledge of their rebellious past - that led the anthropologist to define the African traits brought by the slaves to the Americas. Herskovitz exerted a huge influence on a generation of anthropologists like Arthur Ramos, Roger Bastide and many others in the I940s who studied what they called Afro-Brazilian culture.

The intellectual trajectory of Melville Herskovitz expresses, indeed, a doubt that remains alive in the interpretations concerning the cultures brought by the slaves and their survival in Brazil and the Americas. Had these cultures survived? Had they transformed? In the view of many scholars, African slaves brought cultural traces that were syncretized in the new country, ${ }^{20}$ mixed with the features of Amerindian and European cultures. These traces remained alive and their origins could be discerned by searching in Africa for traits similar to those found in Brazil. The search for Africanisms in Brazil led Brazilian anthropology to dedicate itself for decades to discovering the "true" origin of the rituals, ceremonies, cults and objects encountered.

Herskovitz's vision of what he called Afro-American culture, however, was not the only interpretation concerning the theme of the African heritage. As observed earlier, for Franklin Frazier, another founding hero of the discipline, the African heritage had been extinguished. Frazier, along with Robert Park, Donald Pierson and Ruth Landes, had the same approach and were followers of Franz Boas. Melville Herskovitz, himself a student of Boas, searched for African origins in the Americas. These researchers, though possessing the same historical affiliation to one of the founders of anthropology, Franz Boas, set off on very different paths, as Price and Price (2003) also showed. While the former group were more interested in understanding synchrony, the life of Brazilians and their structural principles, the latter focused on tracing the history, diachrony and origin of life in the New World.

These two paradigms, which I refer to here as "lineages," were maintained for many years during the twentieth century and occupied the minds and research of the anthropologists studying Africa in the Americas: indeed 
they still oscillate today like a pair of scales, tipping sometimes to one side, sometimes to the other.

So which of these traces were brought to Brazil and denominated AfroBrazilian culture? We can list legacies in the family, language, cooking, music, dance and religion. The terms culture of African origin or Afro-Brazilian culture are used, for example, for the spirit possession religion that acquired a variety of different names: candomblé in Bahia, catimbó in the Northeast, umbanda or macumba in Rio de Janeiro, xangô in Recife. This is without mentioning capoeira dancing, food dishes like feijoada, vatapá and caruru, and words of Bantu origin such as cafundó, cachimbo and many others.

Edison Carneiro was caught between the two poles. Ruth Landes was clearly situated in the debate by her intellectual affiliation to Franz Boas, Ruth Benedict, Robert Park, Donald Pierson and Franklin Frazier. Landes preferred to describe the customs and beliefs of the black population of Bahia without searching for origins, as she did in her beautiful book. Edison Carneiro, though influenced by this approach, remained on the threshold between the idea of assimilation, which suggested a new cultural dynamic, and the idea of survivals, which valued the cultural vestiges seen to be authentically African. His relation to Arthur Ramos and the delayed response to the latter's criticisms of Ruth Landes can be explained by his ambiguity over how to conceive of Africa in Brazil.

It is worth turning for a moment to the photos taken by Ruth Landes during her research in Bahia.

As the photos show (pages II6 and II7), the mães-de-santo are always adorned with their starched and twirling dresses. However, there are no underskirts in Africa, because this kind of clothing can only be starched with a lot of sugar and eggs, symbols of power in an affluent society. Imagine starching clothes in traditional societies from which the slaves came! Hence the starched underskirts can be said to materially represent the principle organizing these rituals in Brazil, as I have previously described (Maggie, 200I) through Victor Turner's concept of social drama and inspired by the notion of the power of the weak. ${ }^{21}$

If Ruth Landes, Donald Pierson and Franklin Frazier analysed Brazilian life from the viewpoint that there are no underskirts in Africa, then Arthur Ramos, Roger Bastide and Herskovitz preferred to see Africa in Brazil and forget about the underskirts. Edison Carneiro could be said to have worked on the boundary between these two approaches and his intimate knowledge of caboclo candomblé and contact with the mãe-de-santo Sabina undoubtedly enabled him to see the beauty of the starched underskirts and laceworks as symbols of the grandeur of an Africa constructed by Brazilians.

To conclude, then, this clash was not only present in the I930s, 40 s and 50s: it remains very much alive today. The stance adopted by Edison 
Carneiro at the time would be near enough impossible today. The scales have tipped heavily towards a reification of Africa in what has become consecrated by the expression "African-based cultures or religions." In the same way, the expression Afro-Brazilian has been substituted by the category Afro-descendent.

While the debate was once confined to the field of research, today it has spread through social life as a whole, permeating public policies, especially from 2003 onwards with the promulgation of Law 10.639/03, which obliges all Brazilian schools to teach Afro-Brazilian culture following guidelines that make the teaching of ethnic-racial relations and African and AfroBrazilian history and culture compulsory. There is a lack of studies showing how these guidelines are being absorbed in the everyday life of the schools and whether the scales are tipped more to marking the division of Brazilians between Afro-descendants and Euro-descendants, or more towards seeing the underskirts worn here. ${ }^{22}$

Received on 04/II/2013 | Approved on oI/13/20I4

Yvonne Maggie is a retired professor of the Department of Cultural Anthropology of the Institute of Philosophy and Social Sciences of the Federal University of Rio de Janeiro (IFCS/UFRJ). Author of Guerra de orixá: um estudo de ritual e conflito (200I [I975]), Medo do feitiço: relações entre magia e poder no Brasil (I992) and Raça como retórica: a construção da diferença (2002), the latter co-authored with Claudia Barcelos Rezende. Among other works, she co-edited with Peter Fry a facsimile edition of the Revista Brazileira's publication of $O$ animismo fetichista dos negros baianos by Raimundo Nina Rodrigues (2006). She also writes the blog "A vida como ela parece ser" for the Globo Gi website. 


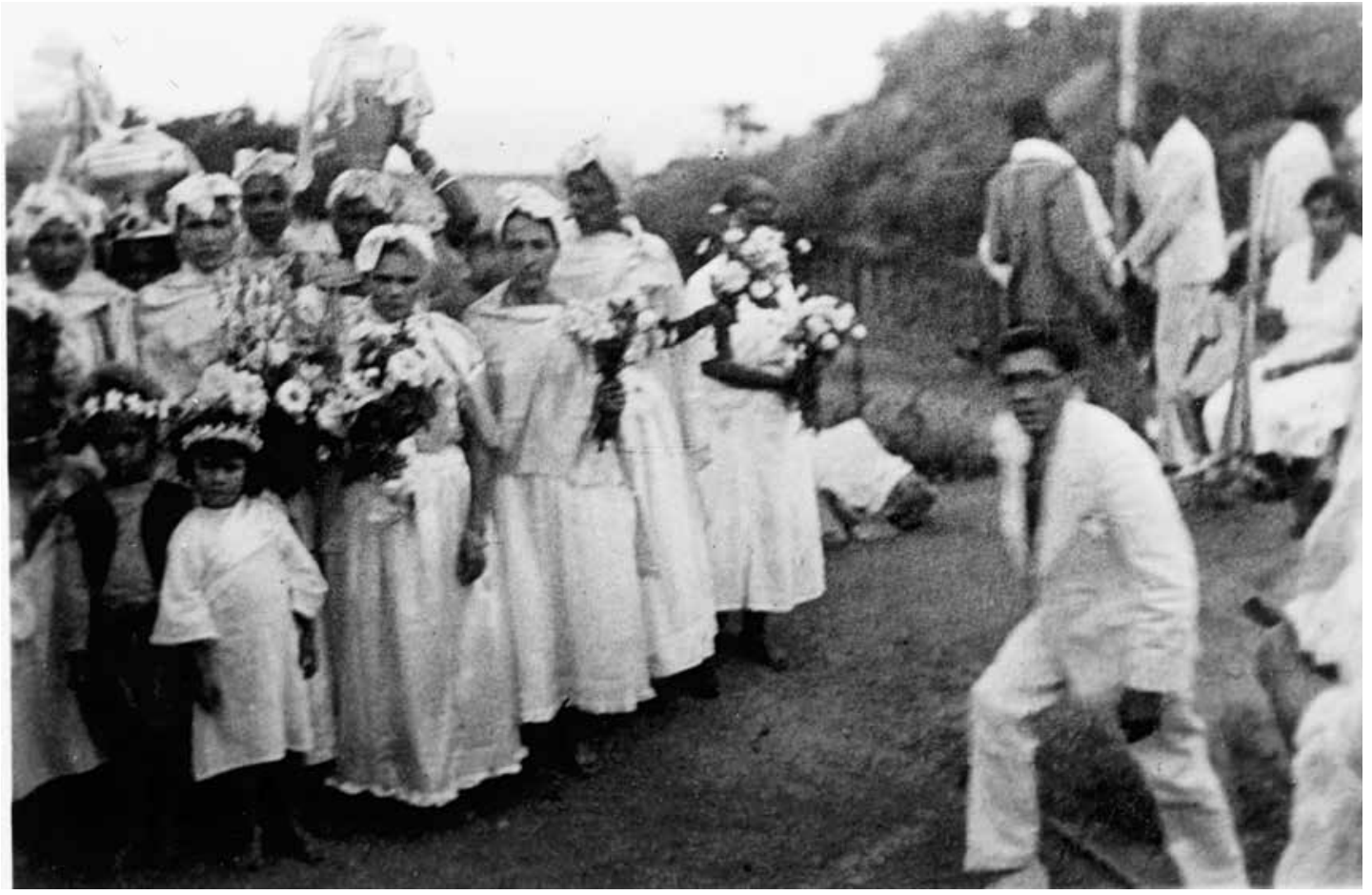




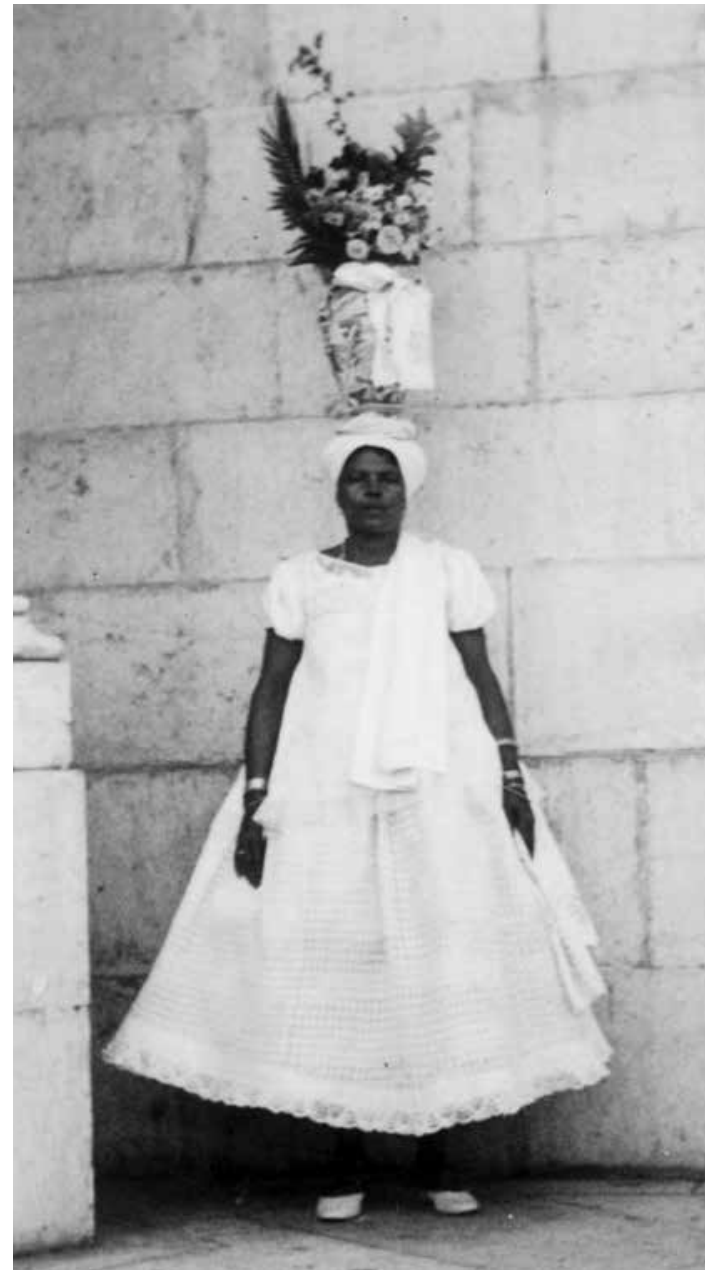

3

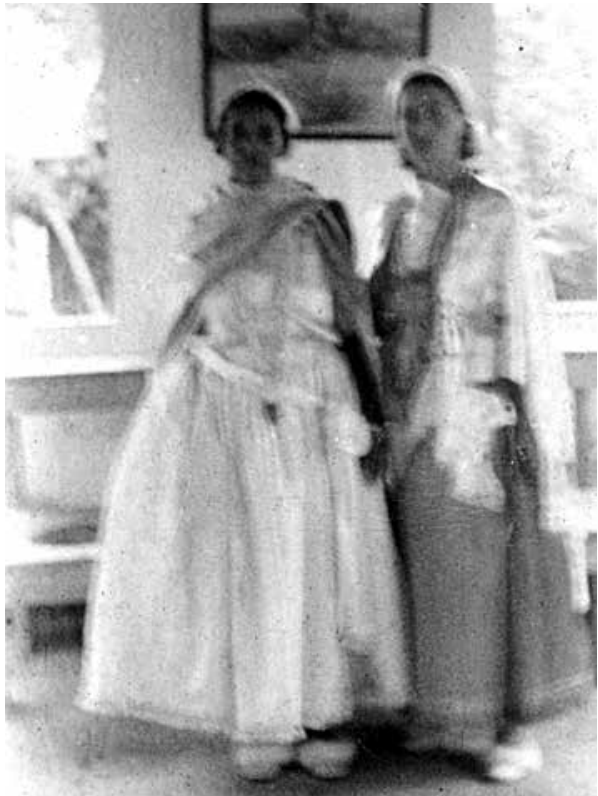

4

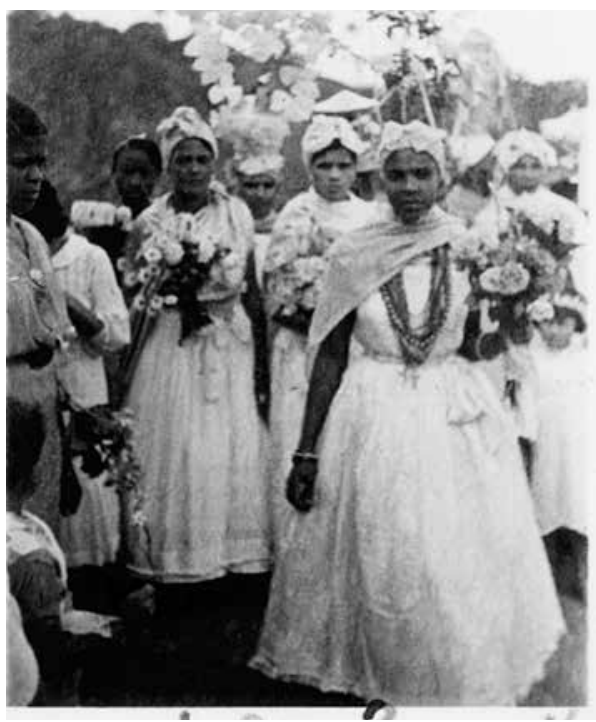

5 dress], I938 September, Smithsonian Institution.

5 [Antonia and filhas of Sabina at offering ceremony to Iemanjá], September, I938, Smithsonian Institution. 


\section{ENDNOTES}

I A first version of this essay was presented on the Free Course in Folklore and Popular Culture, held at the Centro Nacional de Folclore e Cultura Popular (CFCP) [National Center of Folklore and Popular Culture] in 2010, on the theme Biographies: cultural writings and trajectories. The encounter was the first step towards organizing the centenary celebrations of Edison Carneiro's birth in 2012. The following year, on the Postgraduate Program in Sociology and Anthropology at IFCS/UFRJ, Maria Laura Cavalcanti ran a series of talks on Edison Carneiro where I presented my by now more elaborated reflections. The following year I presented the text at the 28th Meeting of ABA in homage of Carneiro's birth centenary. These initiatives provided me with a wonderful opportunity to return to the topic that had pursued me ever since my initiation into anthropology. I wish to thank Claudia Márcia Ferreira and Maria Laura Cavalcanti. I also owe Maria Laura, Glaucia Villas Bôas and André Botelho thanks for their careful reading of my work. I thank Everton Rangel, who kindly transcribed my talk at PPGSA/IFCS. I also thank the anonymous referees for their useful suggestions. The omissions and mistakes are, of course, entirely my own responsibility.

2 The study of so-called Afro-Brazilian religions began at the end of the nineteenth century and the start of the twentieth, initiated by the physician Raimundo Nina Rodrigues, who was born in Maranhão and settled in Bahia. Nina Rodrigues could be said to have produced the first urban ethnography and taken the first steps in constituting the field of study of Afro-Brazilian religions in the nascent discipline of anthropology. His book $\mathrm{O}$ animismo fetichista dos negros baianos (Rodrigues, 2006), published in French, was reviewed by Marcel Mauss in L'Année Sociologique, I900-I90I, p. 224-225. Studies of folklore also incorporated the Afro-Brazilian religions into their research universe. Edison Carneiro moved between the two worlds. On one side, he joined the folklorist movement, while on the other he became one of the founders of the field in anthropology by chaperoning Ruth Landes in Bahia at the end of the I930s. These two fields are, therefore, very closely connected. Edison Carneiro's biography at- 
tests to this proximity since he was one of the founders of the folklorist movement and a collaborator with Arthur Ramos, the leader of the anthropological studies of AfroBrazilian religions with a professorship at what was the University of Brazil, created in 1939.

3 Mãe-de-santo Aninha was the founder of the Ilê Axé Opô Afonjá in Rio de Janeiro in I895, and in Salvador in I9ıo. In 1936, she reinaugurated Ilê Iyá, instituted the Corpo de Obás de Xangô [Ministers of Xangô] with Martiniano Eliseu do Bonfim. She also laid the cornerstone for the new terreiro Ilê N'Lá and founded the Sociedade Cruz Santa [Holy Cross Society], at Ilê Axé Opô Afonjá in Salvador.

4 Mãe-de-santo Senhora was born Maria Bibiana do Espírito Santo on March 3ist I890. Her mother, Claudiana do Espírito Santo, was the daughter of Marcelina da Silva, Oba Tossi, one of the founders of the first candomble house in Brazil - Ilê Axé Airá Intilè, or Candomblé da Barroquinha - and later Casa Branca do Engenho Velho in Salvador. She was initiated by the iyalorixá Eugênia Anna Santos, Mãe-de-santo Aninha, in her house in Ladeira da Praça, in Pelourinho, the historical centre of Salvador. She married Arsênio dos Santos. On December 2nd I9I7, her only child was born, Deoscóredes Maximiniano dos Santos, known as Mestre [Master] Didi. She was the iyalorixá of Ilê Axé Opô Afonjá in Salvador from I942 to I967 and became one of the most important religious leaders in Brazil's history.

5 Ilê Axé Opô Afonjá is one of the terreiros said to be authentically Nagô. It originated from a breakaway sect from the candomblé of Engenho Velho and was founded in Igio.

6 For a rich interpretation of Edison Carneiro's intellectual life and his relation to Marxism, see Rossi (20II).

7 The Columbia University/Bahia State Agreement was conceived by Anísio Teixeira, then State Secretary of Education and Health, during Otávio Mangabeira's term of office (I947-I95I). The objective of the agreement was to inquire into the social life of three rural communities near to Salvador in order to compile information for use in future public policies aimed at modernizing these areas. Charles Wagley - a researcher from Columbia University who was 
in Brazil when the work of the United Nations Organisation for Education, Science and Culture (UNESCO) began, consolidating the research project organised and promoted by the institution - offered to collaborate in a joint endeavour. The idea was accepted by Alfred Métraux and Ruy Coelho, coordinators of what became famous as the UNESCO Project. Wagley also suggested investigating the city of Salvador, which would be placed under the responsibility of physician and anthropologist Thales de Azevedo, one of the coordinators of the Columbia University/Bahia State Project. Ruy Coelho approved of this study of the capital of Bahia. On this project as a whole, see Maio (I999).

8 On the importance of Heloísa Alberto Torres and the history that connects her to Arthur Ramos through Marina São Paulo de Vasconcellos, see Ribeiro (2000).

9 One difference is typically cited when discussing the fundamental distinction between Nagô candomblé and Caboclo candomblé. Nagô candomblé does not worship ancestors but the forces of nature, while Caboclo or Bantu candomblé, or caboclo, which perhaps gave rise to macumba and umbanda, is based more on possession by ancestors: pretos-velhos, caboclos, índios and exu.

Io The term "transplant" or "transplantation," which today may be associated with organ transplants, was undoubtedly associated at the time and referred to the transplantation of plants. To transplant means to take a seed from its place of origin and germinate the tree in other soils. Since modernism, at least, the theme of the transplantation of cultures has been central to Brazilian cultural production. It became an almost conceptual expression in the social sciences through the debate on the national elements of Brazilian life. However, in the literature on the so-called Afro-Brazilian cults or religions, the expression expressed a diffusionist approach, since those studying the topic searched for traces of the African cultures or the regions from which African slaves had come to Brazil in order to identify them with the cultural traits found in the terreiros or temples in Brazil.

I I On the relationship between anthropology at the National Museum during the era of Heloísa Alberto Torres and the recently inaugurated National Faculty of Philosophy, see Ribeiro (2000). 
I2 Roger Bastide was one of the founders of the Brazilian social sciences, a member of the mission of foreign professors at the recently created University of São Paulo. He focused on the study of the candomble of Bahia, but was interested in many other fields of Afro-Brazilian culture, like poetry, music and cults in São Paulo, or macumba. He believed Africa was strongly present in Brazil and was one of those who sought the African authenticity of what he defined as African religion in the country. On this topic, see Dantas (1988).

I3 Maria Laura Cavalcanti (I986) discusses Edison Carneiro's published work and emphasizes its particularity, despite the author following the footsteps of Arthur Ramos in terms of the idea of Nagô purity. Monteiro (I978), Moraes (I986), Fry (I984) and Cavalcanti (I986) discuss the opposition constructed by Ramos, Bastide and Carneiro between umbanda and candomble and underline the ethnocentrism of Bastide's position. I agree with them, although I perhaps identify a more ambiguous stance in Carneiro's work due to the influence that his study of Caboclo candomblé had on his way of thinking.

I4 The book by Beatriz Góis Dantas (1988) was translated into English under the title Nagô Granma and White Papa: Candomble and the creation of Afro-Brazilian identity (Chapel Hill: University of North Caroline Press and Duke University Press, 2009). The English title alters the content of the book, which precisely relativizes the notion of any substantivized identity. This edition also omits the preface by Peter Fry that analysed Dantas' relativizing approach amid the widespread reification of the authenticity of the Nagô terreiros of Bahia. The book was heavily debated because of its relativizing approach and the role that Dantas attributed to Bahian intellectuals in the construction of "Nagô purity."

I5 Her work was subject to intense debate and many criticisms focused on the fact that Dantas had removed the "agency" of the pais-de-santo and mães-de-santo, attributing more power to the intervention of Bahian intellectuals. On this issue, see Serra (1995) and Matory (2005).

I6 In 2006, the year of the hundredth anniversary of Raimundo Nina Rodrigues's birth, the National Library Foundation and Editora UFRJ published a facsimile of the first 
edition of $\mathrm{O}$ animismo fetichista dos negros baianos, published by the Revista Brazileira journal, which preceded its publication in French in I900. See Rodrigues (2006).

I7 It should be pointed out that Oracy Nogueira, one of the researchers of the UNESCO Project, maintained a very different position to that of Roger Bastide and Florestan Fernandes and was more closely aligned with the Donald Pierson's approach, maintaining an intense correspondence with the American researcher, who lived in Brazil from 1935 to I955, up until his death. See Cavalcanti (1996). Also see the Oracy Nogueira Archive, today deposited at the Casa de Oswaldo Cruz.

I8 On this discussion, see Sansone (20II), who explores the topic by emphasizing the transnationality of Brazil in constructing the role of Africa in the emancipation of the black populations of the USA and Brazil.

I9 On the construction of Africa in Brazil, a key work to consult is the book by Fry and Vogt (1996). Researching a black community who claimed to speak an African language, the authors analyse the construction of an identity and its context.

20 On the notion of syncretism and the many paths through which the phenomenon can be analysed, see Ferreti (I995).

2I For my description of rituals in a terreiro in Rio de Janeiro, see Maggie (200I). For a discussion of the power of the weak in Victor Turner's work, see Turner (I974).

22 Some recent works have undertaken this task and I cite those that describe and discuss the construction of a new paradigm: Mariz (2012), Freitas (2010), Rodrigues Junior (2012) and Monteiro (2010).

23 These pictures have been taken and identified by Ruth Landes during his research in Salvador, Bahia. 


\section{BIBLIOGRAPHY}

Andreson, Jamie L. (2012). Carneiro and Ruth Landes: Authority and matriarchy in candomblé field research. Berkeley Undergraduate Journal, 25/I, p. I938-I939.

Bastide, Roger. (I973). O mundo dos candomblés e macumba paulista. In: Estudos afro-brasileiros. São Paulo: Perspectiva.

Bastide, Roger. (I97I). As religiões africanas no Brasil. Contribuições a uma sociologia da interpretação das civilizações. São Paulo: Livraria Pioneira/Edusp. (2 vol.)

Bastide, Roger. (I96I). Candomblés da Bahia. Rito nagô. São Paulo: Cia. Editora Nacional.

Birman, Patrícia. (1995). Possessão e diferenças de gênero em terreiros de umbanda e candomblé no Rio de Janeiro. Rio de Janeiro: Relume Dumará.

Brasil. Lei $n^{\circ}$ I0.639, de Io de janeiro de 2003 - Estabelece o ensino das relações étnico-raciais e da história e cultura africana e afro-brasileira. Diário Oficial [da República Federativa do Brasil], Brasília.

Carneiro, Edison. (1964). Ladinos e crioulos: estudos sobre o negro no Brasil. Rio de Janeiro: Civilização Brasileira.

Carneiro, Edison. (1937). Negros bantos. Rio de Janeiro: Civilização Brasileira.

Carneiro, Edison. (1936). Religiões negras: notas de etnografia religiosa. Rio de Janeiro: Civilização Brasileira.

Carneiro, Edison \& Ferraz, Aidano do Couto. (I940). O negro no Brasil. Rio de Janeiro: Civilização Brasileira.

Cavalcanti, Maria Laura Viveiros de Castro. (I986). Origens, para que as quero? Questões para uma investigação sobre a umbanda. Religião \& Sociedade, I3/2, p. 84 -IоI.

Cavalcanti, Maria Laura Viveiros de Castro. (I996) Oracy Nogueira e a antropologia no Brasil: o estudo do estigma e do preconceito racial. Revista Brasileira de Ciências Sociais. II/3I, p. 5-28.

Dantas, Beatriz Góis. (I988). Vovó nagô e papai branco: usos e abusos da África no Brasil. Rio de Janeiro: Ed. Graal.

Dantas, Beatriz Góis. (2009). Nagô granma and white papa: Candomble and the creation of Afro-Brazilian identity. Chapel Hill: University of North Caroline Press/Duke University Press. 
Frazier, E. Franklin. (1957). Black bourgeoisie: The book that brought the shock of self-revelation to middle-class Blacks in America. Nova York: First Free Press.

Frazier, E. Franklin. (I942). The negro family in Bahia, Brazil. American Sociological Review, 7/4, p. 465-478. Available at:<http://www.jstor.org/discover/I0.2307/2085040? sid $=2$ I I 055685 I $3403 \&$ uid $=4 \&$ uid $=3737664 \&$ uid $=2>$. Ac cessed Io January 2015.

Ferreti, Sergio F. (I995). Repensando o sincretismo. Estudo sobre a Casa das Minas. São Paulo: Edusp.

Freitas, Ludmila Fernandes. (20II). Cumpra-se a lei. MA dissertation. PPGSA/Federal University of Rio de Janeiro. Fry, Peter. (200I). Prefácio. In: Landes, Ruth. A cidade das mulheres. 2. ed. Rio de Janeiro: Ed. UFRJ.

Fry, Peter. (1982). Para inglês ver: identidade e cultura na sociedade brasileira. Rio de Janeiro: Zahar.

Fry, Peter \& Maggie, Yvonne. (2006). Prefácio. In: Rodrigues, Nina. O animismo fetichista dos negros baianos. Rio de Janeiro: Biblioteca Nacional/Ed. UFRJ.

Fry, Peter \& Vogt, Carlos. (1996). Cafundó: a África no Brasil. São Paulo: Companhia das Letras/Ed. Unicamp.

Herskovitz, Melville J. (2005). The myth of the Negro past. Boston: Beacon Press.

Herskovitz, Melville J. (1943). The Negro in Bahia, Brazil: A problem in method. American Sociological Review, 8/4, p. 394404. Available at: <http://www.jstor.org/discover/I0.2307 $/ 2085800$ ? $\operatorname{sid}=2$ I I05863I85I5 I \&uid $=2 \& u i d=4>$. Acessed Io January 2015 .

Landes, Ruth. (2002 [1967]). A cidade das mulheres. Rio de Janeiro: Ed. UFRJ.

Lima, Vivaldo Costa. (1977). Família-de-santo no candomblé gêge-nagô. Salvador: Corrupio.

Lima, Vivaldo Costa \& Oliveira, Waldir Freitas (eds.). (I987). Cartas de Edison Carneiro a Artur Ramos I936-1938. Cidade: Corrupio.

Maggie, Yvonne. (200I [1976]). Guerra de orixá: um estudo de ritual e conflito. Rio de Janeiro: Zahar.

Maio, Marcos Chor. (I999). O Projeto da Unesco e a agen- 
da das ciências sociais do Brasil dos anos 40 e 50. Revista Brasileira de Ciências Sociais, 4/4I, p. I4I-I58.

Mariz, Silviana. (2012). A produção acadêmica sobre as relações raciais no Brasil e no Ceará: A construção da afrodescendência. Ph.D thesis. PPGE/Federal University of Ceará. Matory, J. Lorand. (2005). Black Atlantic religion tradition, transnationalism, and matriarchy in the Afro-Brazilian candomblé. Princeton/Oxford: Princeton University Press.

Mauss, Marcel. (I900-I9oI). L’Année Sociologique, v.5, p. 224-225. Mintz, Sidney \& Price, Richard. (1992). The Birth of African American Culture: an anthropological perspective. Boston: Beacon Press.

Moraes, Eduardo Jardim de. (I986). O idêntico e o diferente - leitura de Roger Bastide. In: Simson, Olga R. de Moraes (ed.). Revisitando a terra de contrastes: a atualidade de Roger Bastide. São Paulo: FFLCH/CERU-USP, p. 97-I05.

Monteiro, Duglas Teixeira. (I978). Roger Bastide: religião e ideologia. Religião e Sociedade, 3, p. II-24.

Monteiro, Fabiano Dias. (2010). Do anti-racismo criminal às ações afirmativas: um estudo sobre o debate político racial no Rio de Janeiro (2000-2007). Ph.D thesis. PPGSA/Federal University of Rio de Janeiro.

Nascimento, Ana Carolina Carvalho de Almeida. (2009). O sexto sentido do pesquisador: a experiência etnográfica de Edison Carneiro. MA dissertation. PPGSA/Federal University of Rio de Janeiro.

Park, Robert. (I97I). Introdução. In: Pierson, Donald. Brancos e pretos na Bahia. São Paulo: Cia. Editora Nacional, p. 79-86. Pierson, Donald. (I97I). Brancos e pretos na Bahia. São Paulo: Cia. Editora Nacional.

Pinto, Roquete. (1936). Estudos afro-brasileiros. Congresso Afro-Brasileiro, I, Recife. Rio de Janeiro: Ariel Editora Ltda. Price, Richard \& Price, Sally. (2003). Root of roots: Or how Afro-American Anthropology Got to Start. Chicago: Prickly Paradigm Press/University of Chicago Press.

Ramos, Arthur. (1942). Pesquisas estrangeiras sobre o negro brasileiro. In: Aculturação do negro no Brasil. Rio de Janeiro: Cia. Editora Nacional (Coleção Brasiliana, 224). 
Ribeiro, Adélia M. (2000). Heloísa Alberto Torres e Marina São Paulo de Vasconcellos: entrecruzamento de círculos e a formação das ciências sociais na cidade do Rio de Janeiro. Ph.D thesis, PPGSA/Federal University of Rio de Janeiro.

Rodrigues, Raimundo Nina. (200I [1898]). O animismo fetichista dos negros baianos. Rio de Janeiro: Biblioteca Nacional/Ed. UFRJ.

Rodrigues, Raimundo Nina. (2008 [1932]). Os africanos no Brasil. São Paulo: Madras.

Rodrigues Junior, Nilton. (2012). Liberdade religiosa ou uma questão de política de identidade. Ph.D thesis. PPGSA/Federal University of Rio de Janeiro.

Rossi, Luiz Gustavo Freitas. (20I I). O intelectual "feiticeiro": Edison Carneiro e o campo de estudo das relações raciais no Brasil. Ph.D thesis. PPGAS/IFCH/Campinas State University.

Sansone, Livio. (20II). USA \& Brazil in Gantois. Virtual Brazilian Anthropology - Vibrant, 8/r. Available at: <http:// www.vibrant.org.br/issues/v8nI/livio-sansone-usa-brazilin-gantois/>. Accessed Io January 2015 .

Santos, Deoscorédes M. dos. (I962). História de um terreiro nagô. Rio de Janeiro: Instituto Afro-Asiáticos.

Serra, Ordep. (I995). Águas do rei. Petrópolis/Rio de Janeiro: Vozes/Koinonia.

Teixeira, Maria Lina Leão. (I986). Transas de um povo-desanto: Um estudo sobre identidades sexuais. MA dissertation. PPGSA/Federal University of Rio de Janeiro.

Turner, Victor. (1974). O processo ritual. Petrópolis: Vozes. Valladares, Licia do Prado. (20I0). A visita do Robert Park ao Brasil, o "homem marginal" e a Bahia como laboratório. Cadernos CRH, 23/58, p. 35-49.

Vilhena, Luiz Rodolfo. (I997). Projeto e missão: o movimento folclórico brasileiro. Rio de Janeiro: Ed. FGV/Funarte 
Palavras-chave Religião afro-brasileira;

Edison Carneiro;

África; Candomblé; Ruth Landes

Keywords Afro-Brazilian Religion; Edison Carneiro;

Africa; Candomblé; Ruth Landes.
NÃO HÁ ANÁGUAS NA ÁFRICA: EDISON CARNEIRO E AS "LINHAGENS" DA ANTROPOLOGIA DAS RELIGIÕES AFRO-BRASILEIRAS

\section{Resumo}

O artigo apresenta o folclorista, ensaísta, jornalista e antropólogo Edison Carneiro (I9I2-I972) e sua posição entre as "linhagens" ou filiações intelectuais no cenário dos estudos sobre os cultos afro-brasileiros. Descreve a vida de Edison Carneiro, sua relação com a antropóloga americana Ruth Landes e sua participação no Movimento Folclórico. Busca-se perceber o seu lugar entre as tendências intelectuais do estudo das religiões afro-brasileiras. Sustenta-se que o autor teve uma posição ambígua em relação à presença da África na constituição das chamadas religiões afro-brasileiras. De um lado, Carneiro se aproxima-se de Ruth Landes, Franklin Frazier, Ruth Benedict, Donald Pierson e Robert Park e, de outro, de Melville Herskovitz, Roger Bastide, Artur Ramos. Seus estudos sobre o candomblé de caboclo expressam essa dupla vinculação.

\section{NO UNDERSKIRTS IN AFRICA:}

EDISON CARNEIRO AND THE “LINEAGES" OF

\section{AFRO-BRAZILIAN RELIGIOUS ANTHROPOLOGY}

\section{Abstract}

The article presents the folklorist, essayist, journalist and anthropologist Edison Carneiro (I9I2-I972) and situates him among the "lineages" or intellectual affiliations in the context of studies on Afro-Brazilian religious groups. Describing the life of Edison Carneiro, his relationship with American anthropologist Ruth Landes and his participation in the folkloric movement, I look to situate Carneiro among the various intellectual trends found within the study of Afro-Brazilian religions. I argue that the author occupied an ambiguous position in terms of the African presence in the constitution of AfroBrazilian religions, showing close proximities to Ruth Landes, Franklin Frazier, Ruth Benedict, Donald Pierson and Robert Park on the one hand, and Melville Herskovitz, Roger Bastide and Arthur Ramos on the other. Carneiro's studies of Candomblé de Caboclo express this double bind. 